\title{
Hand hygiene initiative: comparative study of pre- and postintervention outcomes
}

\author{
Mohammed Fouad ${ }^{1,2}$ and Sheref Eltaher ${ }^{3,4}$
}

${ }^{1}$ Microbiology and Immunology Department, Faculty of Medicine, Benha University, Benha, Egypt. ${ }^{2}$ Public Health Department, Health Sciences College at Al Leith, Umm Al-Qura University, Saudi Arabia. ${ }^{3}$ Department of Family Medicine and Community Medicine, Faculty of Medicine, Taibah University, Taibah, Saudi Arabia. ${ }^{4}$ Department of Public Health and Community Medicine, Faculty of Medicine, Benha University, Benha, Egypt (Correspondence to: Sheref Eltaher: sherif.abdelmonem@fmed.bu.edu.eg).

\begin{abstract}
Background: Adequate hand hygiene is considered the most effective measure to reduce transmission of nosocomial pathogens.

Aims: To determine the effectiveness of infection control intervention to improve compliance with hand hygiene in the Emergency Department, Al-Leith General Hospital, Saudi Arabia, and evaluate bacterial load on hands as a possible indicator of improvement.

Methods: The study consisted of 3 phases: Phase I, measurement of basal hand hygiene compliance level; Phase II, multimodal hand hygiene educational programme was initiated; and Phase III, hand hygiene compliance level was measured again. Data were collected by direct observation of healthcare workers in the emergency department between October 2016 and March 2017, using the standardized World Health Organization method for direct observation, "Five Moments for Hand Hygiene". The intervention comprised health education sessions using direct personal contact. Hands of healthcare workers were sampled during Phases I and III by sterile bag method, and bacterial load was determined.

Results: A total of 1374 opportunities for hand hygiene were observed during the triphase study. Implementation of the interventional hand hygiene educational programme significantly improved compliance with hand hygiene guidelines from $30.7 \%$ to $45.5 \%(P<0.01)$. Log10 bacterial load per hand dropped from 4.97 (standard deviation $=0.32)$ to $4.57(0.47)(P<0.05)$.

Conclusions: Hand hygiene educational programmes were effective in improving compliance in the emergency department, and bacterial load on hands of healthcare workers could be used as an indicator of improvement in hand hygiene compliance.

Keywords: bacterial load, compliance, Five Moments for Hand Hygiene, hand hygiene, infection

Citation: Fouad M; Eltaher S. Hand hygiene initiative: comparative study of pre- and post-intervention outcomes. East Mediterr Health J. 2020;26(2):198-205. https://doi.org/10.26719/2020.26.2.198

Received: 10/01/18; accepted: 11/07/18

Copyright (C) World Health Organization (WHO) 2020. Open Access. Some rights reserved. This work is available under the CC BY-NC-SA 3.o IGO license (https://creativecommons.org/licenses/by-nc-sa/3.o/igo).
\end{abstract}

\section{Introduction}

Healthcare-associated infections (HAIs) are acquired during treatment for another condition and are not present or incubating at the time of admission, and they carry a significant burden of illness and financial costs (1). Approximately $7 \%$ of hospitalized patients in industrialized nations and $10 \%$ in low- and middle-income countries are affected (2).

Hand hygiene is among the most important measures to prevent transmission and acquisition of HAIs (3). Despite recognition of the crucial role of hand hygiene in reducing infection rates, compliance rates among healthcare workers remain low (4). In a systematic review of 96 studies from industrialized nations, the overall average compliance was $40 \%$ (5).

According to the World Health Organization (WHO) the multimodal "Clean Care Is Safer Care" strategy and the "Five Moments for Hand Hygiene" concept should be performed (1) before touching a patient; (2) before aseptic procedures; (3) after risk of body fluid exposure; (4) after touching a patient; and (5) after touching patients' surroundings $(6,7)$.

The emergency department has special environmental conditions that may interfere with proper hand hygiene compliance, including crowding, use of nontraditional care areas such as hallways, frequent interruptions to care delivery, and close proximity of patients, who are often separated only by curtains $(8,9)$. Few other studies have assessed the efficacy of hand hygiene interventions in emergency departments (10-13), and yet fewer have used the WHO "Five Moments for Hand Hygiene". Other studies have used alternative methods (9). Due to the rapid turnover in emergency departments, it is difficult to measure HAI rates as an indicator of improvement. HAIs, by definition, develop after at least 48 hours of hospitalization, and most emergency cases are discharged on the same day.

The aim of this study was to determine the effectiveness of infection control intervention to improve compliance with hand hygiene in the Emergency Department, Al-Leith General Hospital, Saudi Arabia. 
We also evaluated bacterial load on hands as a possible indicator of improvement of hand hygiene compliance.

\section{Methods}

\section{Study setting}

The study was conducted in the Emergency Department at Al-Leith General Hospital, Saudi Arabia, between October 2016 and March 2017. Al-Leith General Hospital is a secondary level hospital with a total capacity of 65 beds. This work was approved by the Bioethics Committee, Health Sciences College at Alith, Umm Al-Qura University.

\section{Study design}

This was an interventional study that consisted of 3 phases: Phase I, the basal hand hygiene compliance level was measured by direct observation; Phase II, a hand hygiene educational programme was offered to healthcare staff working in the hospital emergency department; and Phase III, hand hygiene compliance level was measured again to determine the effect of the intervention.

\section{Observations and calculations}

Data were obtained from 40 observation sessions; 20 in Phase I and 20 in Phase III. Each observational session was $\sim 20$ minutes. The timings of the observation sessions were randomly distributed throughout the day and night. Observations were conducted by trained volunteer students. All professional healthcare providers and students who were working in the emergency department were included in the study. Healthcare workers were divided into 3 professional categories: (1) nurse/nurse student; (2) medical doctor/medical student; and (3) other healthcare workers (therapists/technicians/dietitians/ dentists/students).

Counting of hand hygiene opportunities and hand hygiene actions was based on the WHO Five Moments of Hand Hygiene concept: (1) before touching a patient; (2) before clean/aseptic procedure; (3) after risk of body fluid exposure; (4) after touching a patient; and (5) after touching patients' surroundings $(6,14,15)$.

A hand hygiene opportunity is defined as a moment during healthcare activities when hand hygiene is required, regardless of the number of indications. Several indications may arise simultaneously, creating a single opportunity and requiring a single hand hygiene action (15). Accepted hand hygiene actions include healthcare workers performing alcohol-based hand rubbing or handwashing with soap and water. Hand hygiene compliance was calculated by dividing the number of performed hand disinfections by the number of hand hygiene opportunities. Analyses were stratified by professional group.

$$
\text { Compliance }(\%)=\frac{\text { Actions }}{\text { Opportunities }} \times 100
$$

\section{Training of auditors}

In October 2016, volunteer students were recruited as hand hygiene auditors after a detailed training process. Training included prepared PowerPoint presentations and educational video of actual healthcare workers performing patient care tasks (16). During video watching, the students were asked to observe and report hand hygiene opportunities and actions using the actual observation form that would be used in the study. Later, students were engaged in inter-rater reliability testing, in which a series of hand hygiene practices were co-observed in the emergency department, and disagreements were discussed and resolved according to WHO hand hygiene training tools (16).

\section{Phase I (preintervention: November-December 2016)}

Phase I is referred to as baseline assessment. Hand hygiene compliance rate in the emergency department was determined for the above-mentioned Five Moments of Hand Hygiene by trained assessors. Potential opportunities for hand hygiene were recorded along with the actual number of episodes of hand hygiene. Recording was performed on a special observation form. Observations were done at random times without prior announcement. Observers acted as unobtrusively as possible but disclosed their task readily on enquiry. Observation sessions lasted 20 (5) minutes.

\section{Phase II (intervention: January 2017)}

Phase II was the interventional phase. This was a multimodal intervention that was conducted in the form of health education sessions using direct personal contact by volunteer students; educational lectures that included a live demonstration of hand hygiene techniques; posters that demonstrated the Five Moments of Hand Hygiene; and other posters that emphasized the importance of hand hygiene (e.g., Hand Hygiene Saves Lives). The posters were placed at strategic sites within the emergency department, ensuring availability of alcohol-based hand cleaners and personal protective equipment at all patient care areas. An additional component of the intervention was feedback, which consisted of announcing the compliance results from Phase I to the emergency department staff.

\section{Phase III (postintervention: February-March 2017)}

After the educational interventions, hand hygiene compliance was measured again using the same methods followed in Phase I.

\section{Determining hand bacterial load}

It is difficult to monitor HAI rates among emergency department patients because of the short stays involved. Therefore, we introduced measurement of bacterial load on hands of healthcare workers as an alternative to measure the benefit obtained by improvement in hand hygiene compliance rates. Fifty samples were taken from hands of healthcare workers during Phase I, and another 50 samples were taken during Phase III. Samples were 
taken from the dominant hand in both phases because hand microbiomes differ between dominant and nondominant hands (17). The sampling method was a modified sterile bag adopted from the method used by Larson et al. (18). Sterile peptone water $(50 \mathrm{ml})$ was poured into sterile polyethylene bags, after which, the hand of the healthcare worker was inserted, the bag opening was secured at the wrist with a tourniquet, and the hand was uniformly massaged for 1 minute by the research staff through the wall of the bag. The solution was mixed in the bag and $0.05-\mathrm{ml}$ aliquots of each sampling solution were plated on tryptic soy agar plates (Merck, Darmstadt, Germany). Inocula were spread with bent glass rods. Plates were incubated at $37^{\circ} \mathrm{C}$ under aerobic conditions for 24 hours, and colony-forming units (CFU) were counted, and bacterial load was calculated and expressed as CFU/hand. Bacterial load on hands was compared using the log10-transformed bacterial count.

\section{Statistical analysis}

The data were tabulated, coded and analysed using SPSS for Windows version 20.0. Compliance rates at baseline and follow-up, overall, for the different professional categories, and for different hand hygiene indications were compared using the $\chi^{2}$ test. Paired t test was done to test the significance of the difference in mean CFU counts between Phases I and III. $P<0.05$ was considered significant.

\section{Results}

There were 1374 hand hygiene opportunities during the study. Nurses had the largest number of opportunities $(87.92 \%)$ in comparison to other professional groups (Table 1). Profession-specific analysis revealed that hand hygiene compliance increased significantly in physicians $(187 \%$ of baseline) and nurses (147\% of baseline) (both $P<0.01$ ). The compliance of the other healthcare workers can be considered unchanged since the variation was insignificant $(P$ $=0.926$ ). The total number of hand hygiene actions significantly increased from 203/662 (30.66\%) in Phase I to $324 / 712(45.51 \%)$ in Phase III $(P<0.01)$ (Table 2).

Compliance results revealed that indication-specific differences ranged from $12.21 \%$ (Indication 2) to $48.84 \%$ (Indication 4) at baseline (Tables 3 and 4). Compliance beforepatient contact and before aseptictasks (Indications 1 and 2) was lower compared to that after patient contact (Indications 3-5). Significant improvements were seen only for Indications 1, 2 and 5. The greatest improvement was seen for Indication 2 ( $279 \%$ of baseline; $P<0.01)$, and the lowest for Indication 5 ( $137 \%$ of baseline; $P=0.018$ ).

Bacterial load on hands of healthcare workers was measured in Phases I and III (Figure 1). In phase I before intervention average log CFU/hand was 4.97 (0.32). In Phase III $\log \mathrm{CFU} /$ hand was significantly increased to $4.57(0.47)(P<0.001)$.

\begin{tabular}{|c|c|c|c|c|c|c|}
\hline \multicolumn{7}{|c|}{$\begin{array}{l}\text { Table } 1 \text { Hand hygiene opportunities according to health care } \\
\text { worker professional group }\end{array}$} \\
\hline \multirow{2}{*}{$\begin{array}{l}\text { Professional } \\
\text { group }\end{array}$} & \multicolumn{2}{|c|}{ Phase I } & \multicolumn{2}{|c|}{ Phase III } & \multicolumn{2}{|c|}{ Total } \\
\hline & $n$ & $\%$ & $n$ & $\%$ & $n$ & $\%$ \\
\hline Nurses & 582 & 87.92 & 566 & 79.49 & 1148 & 83.55 \\
\hline Physicians & 71 & 10.73 & 127 & 17.84 & 198 & 14.41 \\
\hline Other & 9 & 1.36 & 19 & 2.67 & 28 & 2.04 \\
\hline Total & 662 & 100.0 & 712 & 100.0 & 1374 & 100.0 \\
\hline
\end{tabular}

\section{Discussion}

The emergency department is an indispensable component of the current healthcare system; nevertheless, it may have special environmental conditions that interfere with proper hand hygiene compliance. Although there have been many interventional studies of hand hygiene, published data from Saudi Arabia are limited and show contradicting results $(19,20)$. Hand hygiene among healthcare workers remains low and there is room for improvement.

In this study, the educational intervention was associated with a significant increase in compliance rate (30.66 to $45.51 \%$ ). This result is similar to previous studies showing that educational interventions improve hand hygiene compliance $(21,22)$. A few studies have reported hand hygiene compliance rates in Saudi Arabia $(13,19,20$, 23,24). Our pre- and postintervention compliance rates (30.66\% and $45.51 \%$, respectively) are inferior to an overall compliance rate of $50.3 \%$ reported previously in Saudi Arabia (13). The lower rate in our study may have been because it was conducted in the emergency department, which had unique environmental conditions that impeded proper application of hand hygiene. In another study conducted in Saudi Arabia, the compliance rate was $62.5 \%$ (19) but the method of calculation was based on classifying healthcare workers as compliant or noncompliant, which is a flawed method, because compliance varies in the same person over time. The international consensus is to measure compliance per opportunity rather than per person. A third study conducted in intensive care units in a Saudi hospital reported a compliance rate of $59 \%$ (23). In a systematic review of 96 studies on hand hygiene, compliance levels in non-intensive care settings were $50-60 \%(5)$, which is superior to the levels obtained in our study. The relatively low level of postintervention compliance $(45.5 \%)$ is comparable to that in other studies performed in the emergency department. This was evident in a study performed in emergency departments where compliance reached $45 \%$ after 2 successive interventions (21).

The relatively low hand hygiene compliance rate in this study $(<50 \%)$ could be attributed to laxity of the pre-existing infection control programme in the study hospital. For example, essential infection control activities 


\begin{tabular}{|c|c|c|c|c|c|c|c|}
\hline \multirow{2}{*}{$\begin{array}{l}\text { Professional } \\
\text { group }\end{array}$} & \multicolumn{2}{|c|}{ Phase I } & \multicolumn{2}{|c|}{ Phase III } & \multicolumn{2}{|c|}{ Total } & \multirow[t]{2}{*}{$P^{*}$} \\
\hline & Opportunities & $\begin{array}{c}\text { HH } \\
\text { Action }\end{array}$ & $\begin{array}{c}\text { Compliance } \\
(\%)\end{array}$ & Opportunities & $\begin{array}{c}\text { HH } \\
\text { Action }\end{array}$ & $\begin{array}{c}\text { Compliance } \\
(\%)\end{array}$ & \\
\hline Nurses & 582 & 183 & 31.44 & 566 & 261 & 46.11 & $<0.001$ \\
\hline Physicians & 71 & 17 & 23.94 & 127 & 57 & 44.88 & 0.004 \\
\hline Other & 9 & 3 & 33.33 & 19 & 6 & 31.58 & 0.926 \\
\hline Total & $662^{a}$ & 203 & 30.66 & 712 & 324 & 45.51 & $<0.001$ \\
\hline
\end{tabular}

${ }^{*}$ Calculated by $\chi^{2}$ test.

${ }^{a}$ Sum of indications is not equal to the sum of opportunities because 1 opportunity may cover 2 overlapping indications.

such as surveillance and auditing were performed irregularly and were merely performed as paperwork. It could also be attributed to the special characteristics of the study settings in the emergency department, as mentioned before. The absence of leadership engagement in this study could also have been partially responsible for the modest improvement. Effective leadership involvement can improve hand hygiene compliance $(25,26)$. Continuing efforts and further interventions are needed to address such issues.

Our results show that physicians had less compliance for hand hygiene than nurses had $(23.9 \%$ vs $31.4 \%$ in Phase $\mathrm{I}$, respectively). This result is in accordance with other local and international studies (13,27). Previous studies have shown that physicians in general show poor compliance with infection control standards (28). This was evident in a study conducted in Saudi Arabia in which adherence rates were reported as $60 \%$ for nurses and $20 \%$ for physicians at the completion of a hand hygiene improvement campaign (13). It is noticeable that although physicians' compliance level was inferior to that of nurses, they showed a higher level of improvement in Phase III.

Our study showed that most hand hygiene opportunities were encountered by nurses (1148/1374; $83.6 \%$ ). This represents an opportunity to target nurses by tailored educational programmes to foster hand hygiene compliance improvements among such an influential

\begin{tabular}{|c|c|c|c|c|}
\hline \multicolumn{5}{|c|}{$\begin{array}{l}\text { Table } 3 \text { Hand hygiene opportunities according to WHO Five } \\
\text { Moments for Hand Hygiene }\end{array}$} \\
\hline \multirow{2}{*}{$\begin{array}{l}\text { Hand hygiene } \\
\text { encounter }\end{array}$} & \multicolumn{2}{|c|}{ Phase I } & \multicolumn{2}{|c|}{ Phase III } \\
\hline & $n$ & $\%$ & $n$ & $\%$ \\
\hline $\begin{array}{l}\text { 1. Before touching a } \\
\text { patient }\end{array}$ & 117 & 17.38 & 116 & 16.11 \\
\hline $\begin{array}{l}\text { 2. Before aseptic } \\
\text { procedures }\end{array}$ & 172 & 25.56 & 217 & 30.14 \\
\hline $\begin{array}{l}\text { 3. After body fluid } \\
\text { exposure risk }\end{array}$ & 87 & 12.93 & 106 & 14.72 \\
\hline $\begin{array}{l}\text { 4. After touching a } \\
\text { patient }\end{array}$ & 172 & 25.56 & 137 & 19.03 \\
\hline $\begin{array}{l}\text { 5. After touching patient } \\
\text { surroundings }\end{array}$ & 125 & 18.57 & 144 & 20.00 \\
\hline Total & $673^{a}$ & 100.0 & 720 & 100.0 \\
\hline
\end{tabular}

${ }^{a}$ Number of opportunities according to Five Moments for Hand Hygiene is larger than according to healthcare worker professional group due to the fact that an opportunity may be counted twice for 2 indications and once for $1 \mathrm{HCW}$ if 2 indications overlapped. group. It has been shown that the level of knowledge and compliance with hand hygiene practice differs significantly among nurses according to years of service; the highest level of knowledge was achieved by nurses with $<1$ year of service, while the highest compliance level was achieved by more experienced nurses (16-20 years of service). The same study showed that higher levels of nurse education (receiving post-basic course) was associated with increased hand hygiene compliance (29). These finding reflects that hand hygiene education should be continuous and target not only newly recruited nurses, but also those with more experience. Other strategies, beside nurse education, that were proved to positively influence hand hygiene compliance include those aimed at social influence within teams and enhanced leadership (30).

Although hand hygiene compliance levels improved in physicians and nurses, there was no significant change in the other groups, which included technicians, therapists and radiologists. However, the number of observed opportunities for this group in Phase I was relatively small, which was reflected in their statistical results. The compliance rate in this group could also have been affected by the difficulty in targeting such a group in educational activities, which were held using a variety of methods, but mainly by interpersonal communication in the emergency department. Therefore, we can speculate that the chance of receiving an educational session is increased by the average period spent by the personnel in the emergency department. Educational and motivational programmes adapted to specific groups of health personnel are needed to address such a situation.

In this study, the compliance rate before patient contact $(23.93 \%)$ was lower than after patient contact (48.84\%). Similar results have been reported in other local (23) and international (21) studies. This is a phenomenon worth mentioning, because, paradoxically, situations that pose more risk of infection to patients are associated with less hand hygiene compliance from healthcare workers. Hand hygiene before patient contact and before aseptic tasks (Indications 1 and 2) plays a major role in controlling HAIs and avoiding cross-transmission of multiresistant bacteria, thus compliance with these 2 indications is a cornerstone in infection control (6). These 2 indications also showed the highest percentage of improvement after intervention; Indication 2, in particular, showed 


\begin{tabular}{|c|c|c|c|c|c|c|c|}
\hline \multirow{2}{*}{$\begin{array}{l}\text { Hand hygiene } \\
\text { indication }\end{array}$} & \multirow[b]{2}{*}{ Opportunities } & \multicolumn{2}{|l|}{ Phase I } & \multicolumn{2}{|l|}{ Phase III } & \multirow[b]{2}{*}{$\begin{array}{c}\text { Compliance } \\
(\%)\end{array}$} & \multirow[t]{2}{*}{$P^{*}$} \\
\hline & & $\begin{array}{c}\text { HH } \\
\text { Action }\end{array}$ & $\begin{array}{c}\text { Compliance } \\
(\%)\end{array}$ & Opportunities & $\begin{array}{c}\text { HH } \\
\text { Action }\end{array}$ & & \\
\hline $\begin{array}{l}\text { 1. Before touching a } \\
\text { patient }\end{array}$ & 117 & 28 & 23.93 & 116 & 53 & 45.69 & $<0.001$ \\
\hline $\begin{array}{l}\text { 2. Before aseptic } \\
\text { procedures }\end{array}$ & 172 & 21 & 12.21 & 217 & 74 & 34.10 & 0.004 \\
\hline $\begin{array}{l}\text { 3. After body fluid } \\
\text { exposure risk }\end{array}$ & 87 & 27 & 31.03 & 106 & 43 & 40.57 & 0.926 \\
\hline $\begin{array}{l}\text { 4. After touching a } \\
\text { patient }\end{array}$ & 172 & 84 & 48.84 & 137 & 81 & 59.12 & $<0.001$ \\
\hline $\begin{array}{l}\text { 5. After touching patient } \\
\text { surroundings }\end{array}$ & 125 & 48 & 38.40 & 144 & 76 & 52.78 & 0.02 \\
\hline
\end{tabular}

more than double improvement (12.21\% to $34.1 \%)$. The ignorance of Indication 2 (before aseptic procedure) may have been due to an incorrect assumption that performing hand hygiene before patient contact was enough, and this misconception could be corrected by administering proper hand hygiene education.

The difficulty in targeting particular groups of health personnel, the need to improve the modest adherence to hand hygiene in emergency departments, as well as the need to achieve sustainable improvement, all impose challenging demands on healthcare organizations to develop and maintain an innovative and multidisciplinary approach to improve adherence to hand hygiene. Successful and sustained hand hygiene improvement can be achieved by implementing multiple actions to tackle different obstacles and behavioural barriers. WHO has proposed a multimodal strategy that includes 5 key components: (1) supportive infrastructure; (2) training and education; (3) evaluation and feedback; (4) reminders in the workplace; and (5) creating an institutional safety awareness climate (31). All these elements were implemented in the present study.

Suggestions for further improvements to be implemented include patient participation and leadership involvement. These components were missing from the current study. Patient participation has been shown to be effective in improving compliance (32) and is increasingly recognized as an important item to be included in multimodal strategies to improve hand hygiene adherence (33). Leadership involvement was also absent from our study. Absence of leadership has been linked with loss of sustainable change in hand hygiene compliance (34). Other studies have shown that inclusion of administrative leadership is linked with improvements in hand hygiene compliance rates and most importantly with enhanced sustainability of such improvements $(25,26)$.

Measurement of HAI rates as an indicator of improved hand hygiene in emergency departments is difficult due to rapid patient turnover rate. This study attempted to evaluate bacterial hand load as an indicator of improvement after infection control intervention. It has been demonstrated previously that there are significant differences in mean CFU counts before and after handwashing according to frequency of hand washing; bacterial counts tend to decrease with increasing frequency of hand washing (35). We tried to use bacterial load on healthcare workers' hands as an indirect indicator of overall hand hygiene compliance. The average bacterial load per hand decreased significantly, which suggests that average bacterial load on hands of healthcare workers can be used as an objective measurement for overall hand hygiene compliance. Although bacterial load count tends to show great variability from person to person and from time to time, we showed that change in the average count may be used as an indicator for overall compliance. It is difficult to prove the validity of this method due to natural variability of bacterial count

Figure 1 Box and whisker plots showing bacterial load on hands of healthcare workers measured during Phases I and III.

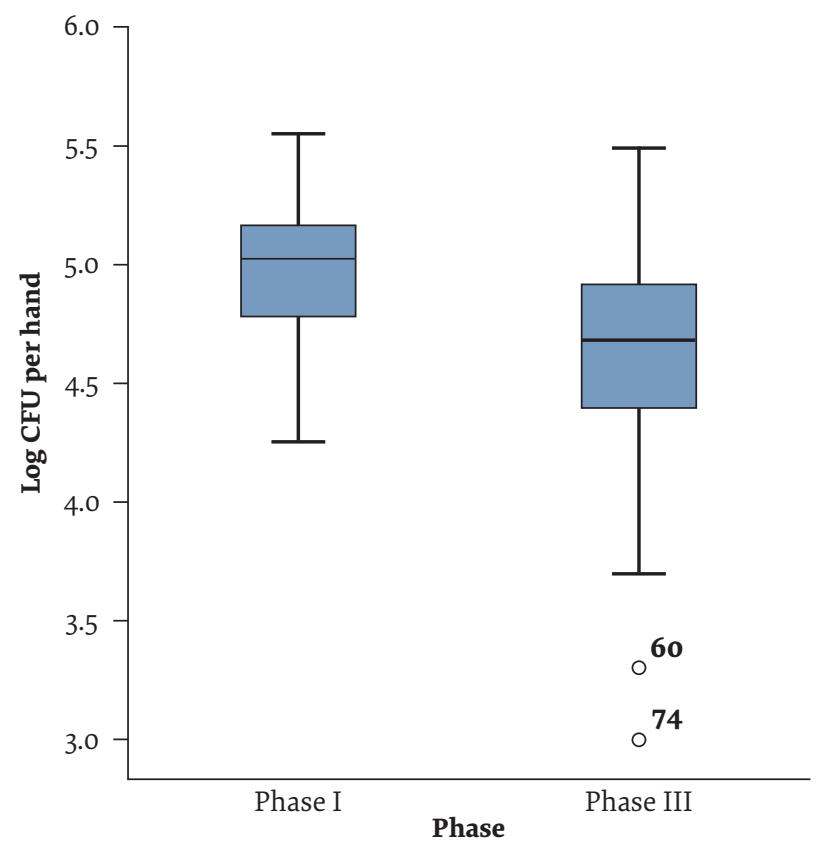


on hands of healthcare personnel throughout the day. This is evident in Figure 1, which shows a wide range of bacterial counts in both phases of the study. Further research is needed to enhance the validity of this method to be used in clinical scenarios.

The limitations of our study included the lack of leadership and patient involvement. We measured shortterm improvement, and repeated measurement of sustained improvement over the long term was not performed.

\section{Conclusion}

Educational intervention was effective in improving hand hygiene compliance. Average bacterial load on hands of healthcare workers may be used as an additional indicator of overall compliance with hand hygiene procedures, especially in rapid patient turnover areas such as emergency departments.

Funding: None.

Competing interests: None declared.

\section{Initiative en faveur de l'hygiène des mains : étude comparative des résultats pré- et post-intervention}

\section{Résumé}

Contexte : Une hygiène des mains adéquate est considérée comme la mesure la plus efficace pour réduire la transmission des agents pathogènes nosocomiaux.

Objectifs : Déterminer l'efficacité d'une intervention visant à améliorer le respect des règles d'hygiène des mains pour la lutte contre les infections au service des urgences de l'Hôpital général d'Al-Leith, en Arabie saoudite, et évaluer la charge bactérienne sur les mains comme indicateur d'amélioration possible.

Méthodes : L'étude s'est déroulée en trois phases : Phase I, évaluation du niveau de conformité avec les règles de base d'hygiène des mains ; Phase II, lancement d'un programme multimodal d'éducation en matière d'hygiène des mains ; et Phase III, nouvelle évaluation du niveau de conformité avec les règles de base d'hygiène des mains. Les données collectées découlent de l'observation directe du personnel soignant du service des urgences entre octobre 2016 et mars 2017 , en utilisant la méthode d'observation directe standardisée de l'Organisation mondiale de la Santé, les « 5 indications pour l'hygiène des mains ». L'intervention comprenait des sessions d'éducation pour la santé avec contact personnel direct. Des échantillons ont été prélevés sur les mains du personnel soignant durant les Phases I et III selon la méthode du sac stérile afin de déterminer la charge bactérienne.

Résultats : Au total, l'observation a permis de relever 1374 opportunités d'amélioration de l'hygiène des mains durant l'étude en trois phases. La mise en œuvre du programme interventionnel d'éducation en matière d'hygiène des mains a permis d'améliorer de manière significative la conformité avec les règles d'hygiène des mains, qui est passée de 30,7\% à $45,5 \%(p<0,01)$. La charge bactérienne logarithmique $(\log 10)$ par main a chuté, passant de 4,97 (écart type $=0,32)$ à $4,57(0,47)(p<0,05)$.

Conclusions : Les programmes d'éducation en matière d'hygiène des mains se sont avérés efficaces pour améliorer la conformité dans le service des urgences. La charge bactérienne sur les mains des agents de soins de santé pourrait servir d'indicateur d'amélioration du degré de conformité avec les règles d'hygiène des mains.

$$
\begin{aligned}
& \text { مبادرة نظافة الأيدي: دراسة مقارنة للمخر جات قبل التدخل وبعده } \\
& \text { محمد فؤاد، شريف الطاهر } \\
& \text { الخالاصة } \\
& \text { الخلفية: تُعد نظافة الأيدي الكافية أكثر التدابير فعالية للحد من انتقال الجراثيم المستشفوية. }
\end{aligned}
$$

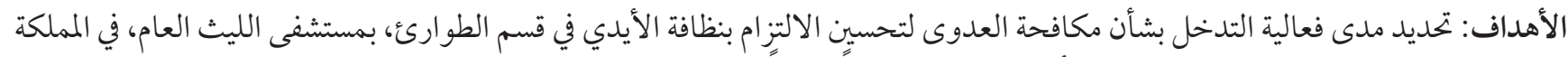

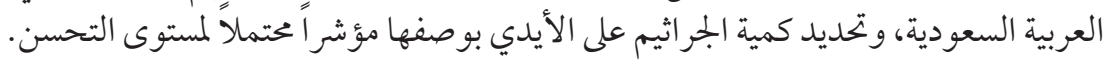

$$
\begin{aligned}
& \text { طرق البحث: تكونت الدر اسة من ب مراحل: المرحلة الأولى: قياس المستوى القاعدي للالتزام بنظافة الأيدي؛ والمر حلة الثانية: بدء تنفيذ برنامج تثقيفي }
\end{aligned}
$$

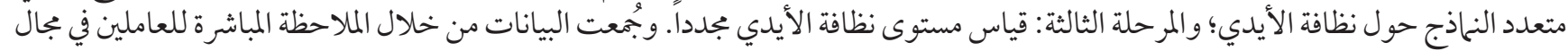

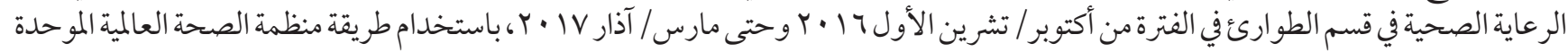

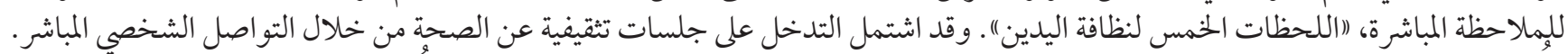

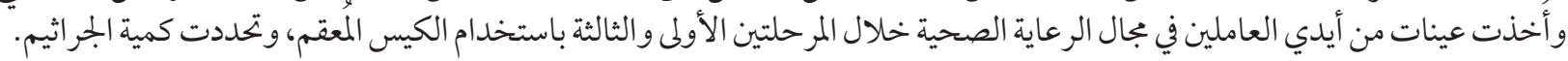

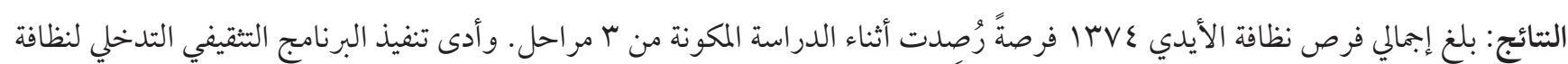

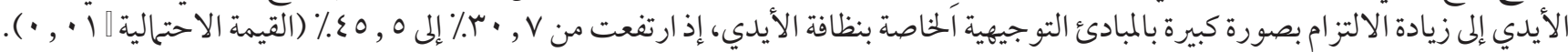




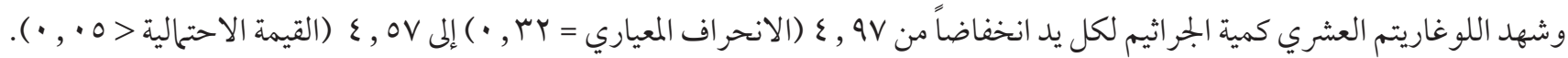

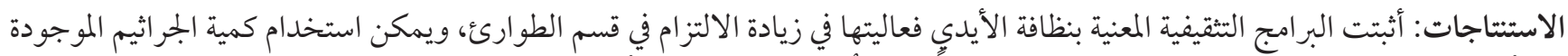

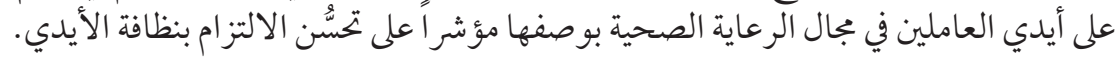

\section{References}

1. Pittet D, Allegranzi B, Storr J, Donaldson L. 'Clean Care is Safer Care': the Global Patient Safety Challenge 2005-2006. Int J Infect Dis. 2006 Nov;10(6):419-24. http://dx.doi.org/10.1016/j.ijid.2006.06.001 PMID:16914344

2. Report on the burden of endemic health care-associated infection worldwide. Geneva: World Health Organization; 2011 (https:// apps.who.int/iris/bitstream/handle/10665/80135/9789241501507_eng.pdf;jsessionid=A1D9102FBF66AFA2A8EAA1EE40898CBE?sequence $=1$, accessed 13 August 2019).

3. Boyce JM, Pittet D. Guideline for Hand Hygiene in Health-Care Settings: recommendations of the Healthcare Infection Control Practices Advisory Committee and the HICPAC/SHEA/APIC/IDSA Hand Hygiene Task Force. Infect Control Hosp Epidemiol. 2002 Dec;23(12 Suppl):S3-40. http://dx.doi.org/10.1086/503164 PMID:12515399

4. Mukerji A, Narciso J, Moore C, McGeer A, Kelly E, Shah V. An observational study of the hand hygiene initiative: a comparison of preintervention and postintervention outcomes. BMJ Open. 2013 3(5). http://dx.doi.org/10.1136/bmjopen-2013-003018 PMID:23793705

5. $\quad$ Erasmus V, Daha TJ, Brug H, Richardus JH, Behrendt MD, Vos MC, et al. Systematic review of studies on compliance with hand hygiene guidelines in hospital care. Infect Control Hosp Epidemiol. 2010 Mar;31(3):283-94. http://dx.doi.org/10.1086/650451 PMID:20088678

6. WHO guidelines on hand hygiene in health care : first global patient safety challenge : clean care is safer care. Geneva: World Health Organization; 2009 (https://apps.who.int/iris/bitstream/handle/10665/44102/9789241597906_eng.pdf?sequence=1, accessed 13 August 2019).

7. Pittet D, Allegranzi B, Sax H, Bertinato L, Concia E, Cockson B. Considerations for a WHO European strategy on healthcare-associated infection, surveillance, and control. Lancet Infect Dis. 2005 Apr;5(4):242-50. http://dx.doi.org/10.1016/s1473-3099(05)700554 PMID:15792742

8. Carter EJ, Wyer P, Giglio J, Jia H, Nelson G, Kauari VE, et al. Environmental factors and their association with emergency department hand hygiene compliance: an observational study. BMJ Qual Saf. 2016 May;25(5):372-8. http://dx.doi.org/10.1136/ bmjqs-2015-004081 PMID:26232494

9. Carter EJ, Pouch SM, Larson EL. Common infection control practices in the emergency department: a literature review. American Journal of Infection Control. 2014 Sep;42(9):957-62. http://dx.doi.org/10.1016/j.ajic.2014.01.026 PMID:25179326

10. Haas JP, Larson EL. Impact of wearable alcohol gel dispensers on hand hygiene in an emergency department. Acad Emerg Med. 2008 Apr;15(4):393-6. 10.1111/j.1553-2712.2008.00045.x PMID:18370997

11. Saint S, Conti A, Bartoloni A, Virgili G, Mannelli F, Fumagalli S, et al. Improving healthcare worker hand hygiene adherence before patient contact: a before-and-after five-unit multimodal intervention in Tuscany. Qual Saf Health Care. 2009 Dec;18(6):42933. http://dx.doi.org/10.1136/qshc.2009.032771 PMID:19955452

12. Saint S, Bartoloni A, Virgili G, Mannelli F, Fumagalli S, di Martino P, et al. Marked variability in adherence to hand hygiene: a 5-unit observational study in Tuscany. Am J Infect Control. 2009 May;37(4):306-10. http://dx.doi.org/10.1016/j.ajic.2008.08.004 PMID:19135761

13. Bukhari SZ, Hussain WM, Banjar A, Almaimani WH, Karima TM, Fatani MI. Hand hygiene compliance rate among healthcare professionals. Saudi Med J. 2011 May;32(5):515-9. PMID:21556474

14. Sax H, Allegranzi B, Uckay I, Larson E, Boyce J, Pittet D. 'My five moments for hand hygiene': a user-centred design approach to understand, train, monitor and report hand hygiene. J Hosp Infect. 2007 Sep;67(1):9-21. http://dx.doi.org/10.1016/j. jhin.2007.06.004 PMID:17719685

15. Hand hygiene technical reference manual: to be used by health-care workers, trainers and observers of hand hygiene practices Geneva: World Health Organization; 2009 (https://apps.who.int/iris/bitstream/handle/10665/44196/9789241598606_eng.pdf?sequence $=1$ \&isAllowed $=y$, accessed 13 August 2019).

16. Tools for training and education. Geneva: World Health Organization; 2012 (https://www.who.int/gpsc/5may/tools/training_education/en/, accessed 13 August 2019).

17. Fierer N, Hamady M, Lauber CL, Knight R. The influence of sex, handedness, and washing on the diversity of hand surface bacteria. Proc Natl Acad Sci U S A. 2008 Nov18;18;105(46):17994-9. http://dx.doi.org/10.1073/pnas.0807920105 PMID:19004758

18. Larson EL, Strom MS, Evans CA. Analysis of three variables in sampling solutions used to assay bacteria of hands: type of solution, use of antiseptic neutralizers, and solution temperature. J Clin Microbiol. 1980 Sep;12(3):355-60. PMID:7012171

19. Abdraboh SN, Milaat W, Ramadan IK, Al-Sayes FM, Bahy KM. Hand hygiene and health care associated infection: an intervention study. Am J Med Med Sci. 2016;6(1):7-15 http://dx.doi.org/10.5923/j.ajmms.20160601.02 
20. Basurrah MM, Madani TA. Handwashing and gloving practice among health care workers in medical and surgical wards in a tertiary care centre in Riyadh, Saudi Arabia. Scand J Infect Dis. 2006;38(8):620-4. http://dx.doi.org/10.1080/00365540600617025 PMID:16857605

21. Scheithauer S, Kamerseder V, Petersen P, Brokmann JC, Lopez-Gonzalez L-A, Mach C, et al. Improving hand hygiene compliance in the emergency department: getting to the point. BMC Infect Dis. 2013 Aug 7;13(1):367. http://dx.doi.org/10.1186/1471-2334-13-367

22. Creedon SA. Healthcare workers' hand decontamination practices: compliance with recommended guidelines. J Adv Nurs. 2005 Aug;51(3):208-16. http://dx.doi.org/10.1111/j.1365-2648.2005.03490.x PMID:16033588

23. Mahfouz AA, El Gamal MN, Al-Azraqi TA. Hand hygiene non-compliance among intensive care unit health care workers in Aseer Central Hospital, south-western Saudi Arabia. International Journal of Infectious Diseases. 2013 Sep;17(9):e729-e32. http://dx.doi. org/10.1016/j.ijid.2013.02.025 PMID:23602356

24. ALSofiani AM, AlOmari F, AlQarny M. Knowledge and practice of hand hygiene among healthcare workers at Armed Forces Military Hospitals, Taif, Saudi Arabia. Int J Med Sci Public Health, 2015;5(6):1282-91. http://dx.doi.org/10.5455/ijmsph.2016.15042016439

25. Midturi JK, Narasimhan A, Barnett T, Sodek J, Schreier W, Barnett J, et al. A successful multifaceted strategy to improve hand hygiene compliance rates. Am J Infect Control. 2015 May 1;43(5):533-6. http://dx.doi.org/10.1016/j.ajic.2015.01.024 PMID:25769618

26. Staines A, Amherdt I, Lecureux E, Petignat C, Eggimann P, Schwab M, et al. Hand Hygiene Improvement and Sustainability: Assessing a Breakthrough Collaborative in Western Switzerland. Infect Control Hosp Epidemiol. 2017 Dec;38(12):1420-27. http:// dx.doi.org/10.1017/ice.2017.180 PMID:28899451

27. Han K, Dou FM, Zhang LJ, Zhu BP. [Compliance on hand-hygiene among healthcare providers working at secondary and tertiary general hospitals in Chengdu]. Zhonghua Liu Xing Bing Xue Za Zhi. 2011 Nov;32(11):1139-42 (in Chinese). PMID:22336552

28. Venier AG, Zaro-Goni D, Pefau M, Hauray J, Nunes J, Cadot C, et al. Performance of hand hygiene in 214 healthcare facilities in South-Western France. J Hosp Infect. 2009 Mar;71(3):280-82. http://dx.doi.org/10.1016/j.jhin.2008.11.020 PMID:19162370

29. Ho SE, Ho CC, Hng SH, Liu CY, Jaafar MZ, Lim B. Nurses compliance to hand hygiene practice and knowledge at Klang Valley hospital. Clin Ter. 2013;164(5):407-11. http://dx.doi.org/10.7417/ct.2013.1604 PMID:24217826

30. Huis A, Holleman G, van Achterberg T, Grol R, Schoonhoven L, Hulscher M. Explaining the effects of two different strategies for promoting hand hygiene in hospital nurses: a process evaluation alongside a cluster randomised controlled trial. Implementation Sci. 2013 Apr 8;Article number 41. https://implementationscience.biomedcentral.com/articles/10.1186/1748-5908-8-41

31. A guide to the implementation of the WHO multimodal hand hygiene improvement strategy. Geneva: World Health Organization; 2009 (https://apps.who.int/iris/handle/10665/70030, accessed13 August 2019).

32. McGuckin M, Waterman R, Porten L, Bello S, Caruso M, Juzaitis B, et al. Patient education model for increasing handwashing compliance. Am J Infect Control. 1999 Aug;27(4):309-14. PMID:10433668

33. Lastinger A, Gomez K, Manegold E, Khakoo R. Use of a patient empowerment tool for hand hygiene. Am J Infect Control. 2017 Aug 1;45(8):824-29. http://dx.doi.org/10.1016/j.ajic.2017.02.010 PMID:28768590

34. Lieber SR, Mantengoli E, Saint S, Fowler KE, Fumagalli C, Bartolozzi D, et al. The effect of leadership on hand hygiene: assessing hand hygiene adherence prior to patient contact in 2 infectious disease units in Tuscany. Infect Control Hosp Epidemiol. 2014 Mar;35(3):313-6. http://dx.doi.org/10.1086/675296 PMID:24521600

35. Larson E. Effects of handwashing agent, handwashing frequency, and clinical area on hand flora. American Journal of Infection Control. Am J Infect Control. 1984 Apr;12(2):76-82 https://doi.org/10.1016/0196-6553(84)90020-8 PMID:6563870 